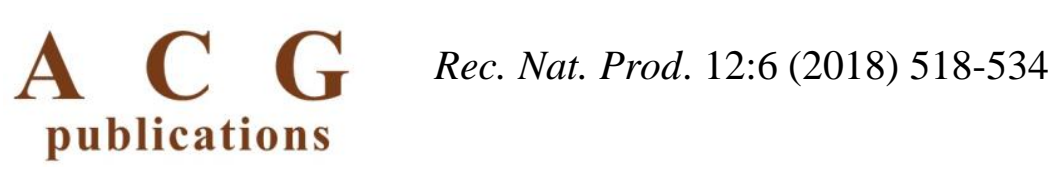

records of natural products

\title{
Antioxidant and Anti-inflammatory Activities of Marantodes pumilum (Blume) Kuntze and Their Relationship with the Phytochemical Content
}

\author{
Shihab Uddin Ahmad ${ }^{\oplus}$, 'Atiqah Azam ${ }^{\oplus}$, Ahmad Nazrun Shuid ${ }^{\odot}$ and \\ Isa Naina Mohamed ${ }^{\oplus *}$ \\ Department of Pharmacology, Faculty of Medicine, Universiti Kebangsaan Malaysia, Jalan \\ Yaacob Latif, Bandar Tun Razak, Cheras, Kuala Lumpur, Malaysia
}

(Received November 29, 2017; Revised February 13, 2018; Accepted February 14, 2018)

\begin{abstract}
Marantodes pumilum is a herbaceous plant that has widely recognized for its medicinal use. The plant used widely has led to many studies on its phytochemical identification, pharmacological and toxicological activities. Phytoconstituents found in the Marantodes pumilum extracts showed high antioxidant and antiinflammatory properties which are essential for many pharmacological effects. The aim of the systematic review is to provide the information of antioxidant and anti-inflammatory properties found in Marantodes pumilum. A critical literature search from three electronic databases such as SCOPUS, EBSCOhost and Ovid Medline was conducted for related studies published from the years 1946 to November 2017. The research studies published in English and related with the antioxidant and anti-inflammatory effects of Marantodes pumilum were the main inclusion criteria in this review. A total 512 relevant articles was identified, whereby 21 articles met the inclusion criteria. Twelve chemical assay studies, five animal studies, two in vitro cell culture study, one combined in vivo animal and chemical study and one combined chemical assay and in vitro cell culture study included in this review. All of the studies reported moderate to noticeable positive effects of Marantodes pumilum against oxidation and inflammation. This systematic review highlights the antioxidant and antiinflammatory effects and their relation with phytoconstituents of Marantodes pumilum extracts.
\end{abstract}

Keywords: Marantodes pumilum; Primulaceae; antioxidant; anti-inflammatory; phytoconstituents. (C) 2018 ACG Publications. All rights reserved.

\section{Introduction}

Medicinal plants are used extensively as remedies for human health since ancient times due to its therapeutic efficacy associated with their purified constituents. At present, more than 2,000 species of medicinal plants have been discovered with therapeutic effects in Malaysia [1]. People have used them as healthcare medication for many centuries. Kacip Fatimah is one of the most popular and widely used herbal plants in Malaysia. Malaysian government has funded to be developed this plant for commercials purposes. The scientific name of Kacip Fatimah is Marantodes pumilum (Blume)

\footnotetext{
${ }^{*}$ Corresponding author: E-Mail: isanaina@ppukm.ukm.edu.my; Phone: +60391459545, Fax: +60391459547
} 
Kuntze (M. pumilum). M. pumilum also known as other scientific names previously like Labisia pumila (Blume) Fern-Vill and Ardisia pumila. It belongs to Primulaceae family that mostly found in the South East Asian countries [2]. This plant is also known to local people as Rumput Siti Fatimah, Selusuh Fatimah, Akar Fatimah, Kachit Fatimah, Mata Pelandok Rimba, Pokok Pinggang, Bunga Belangkas Hutan, Tadah Matahari and Rumput Palis [3]. M. pumilum has found eight species in Malaysia [4]. Three species of them like M. pumilum var. pumila, var. alata and var. lanceolata have studied mostly [5]. These species look different from each other based on their petiole and leaf structure. M. pumilum var. pumila contains petiole that likes as marginated and var. alata one looks winged petiole. However, M. pumilum var. lanceolata contains non-winged petiole [6].

In Malaysia, M. pumilum is a popular medicinal plant that has long been recognized and much demanded its value as female tonics and health products [7]. Traditionally Malay women have been taken raw extracts, obtained by boiling the plants during child delivery. People are commonly believed that the plant extracts can make ease child delivery and help to reduce delivery pain. It can also help to maintain menstrual cycle regularly and relieve the menopausal symptoms [8]. The plant extracts can also drink to boostthe body strength. It also uses to treat common diseases such as dysentery, rheumatism, and gonorrhea [9]. It is also used to inhibit the formation of gas and enhance the abdominal muscles tonicity [10]. It has further been reported to reduce the risk of osteoporosis $[11,12]$, metabolic disorders [13] and cardiovascular diseases [14].

Numerous studies of $M$. pumilum have been determined the bioactive phytochemicals contributing to its numerous pharmacological activities including phytoestrogenic, anti-inflammatory, anti-oxidant, anti-carcinogenic, anti-fungal and anti-microbial effects [15-17]. M. pumilum contains many phytochemicals such as flavonoid and phenolic compounds, methyl gallate, carotenoids, ascorbic acids, fatty acids, saponins, alkenyl compounds and benzoquinone derivatives [18-21]. Phenolic compounds are the secondary metabolites showed the most antioxidant effects. It is believed that the digestive system can easily absorb phenolic acids and they offer numerous anti-aging benefits. The antioxidant activity might indirectly contribute to the reported anti-inflammatory, anticarcinogenic, anti-bacterial and anti-viral properties. Flavonoids are most common sub-group of polyphenols which also known as secondary plant metabolites. Flavonoids have potential benefits for health promotion. Numerous studies showed that flavonoids have many biological effects such as antiviral, anti-allergic, antiplatelet, anti-inflammatory, anti-diarrheal and anti-tumor properties [22]. Flavonoids mainly apigenin, rutin, kaempferol, and myricetin were identified from M. pumilum var. alata. It has also identified phenolic compounds such as pyrogallol, gallic acid and caffeic acid [16, 18]. Methyl gallate could induce many biological effects such as anti-oxidant, anti-asthmatic, antimicrobial, protein tyrosine kinases inhibitor and collagenase inhibitor [23]. $\beta$-carotene has found in the $M$. pumilum extracts [24]. The $\beta$-carotene content was higher in $M$. pumilum var. alata than $M$. pumilum var. pumila. Study reorted that $\beta$-carotene has protective effect. $\beta$-carotene supplementation can protect the skin damage from sunlight [25]. Ascorbic acid (vitamin C), another powerful antioxidative compound identified from the extract of M. pumilum var. pumila and M. pumilum var. alata [24]. It is a common perception that this vitamin $C$ could reduce the risk of strokes by decreasing systolic blood pressure. It can also protect many chronic diseases [26]. It can inhibit oxidation by free radicals accumulated in the human body. Usually, people consume the vitamin $\mathrm{C}$ to boost their immune system.

Many phytochemicals such as tannins, alkaloids, glycosides, sterols, anthocyanins, phenols and triterpenoids are responsible for anti-inflammatory activities. These phytoconstituents which are present in the bark exerted the desired pharmacological effects on the body and thus act as a natural anti-inflammatory agent. Inflammation may cause for many diseases such as polymyalgia rheumatica, chronic arthritis, gouty arthritis, tendonitis, inflammatory bowel disease, heart disease, cancer, and asthma [27,28]. During inflammatory responses, the membrane lipid can release more arachidonec acid by inducing phospholipase A2 [29]. The arachidonic acid produces prostaglandins with the presence of two enzymes including cyclooxygenase-1 (COX-1) and cyclooxygenase-2 (COX-2) [27, 29]. Prostaglandins are associated many cytokines which cause of many pain-related diseases [30]. Phenolic compounds such as flavonoids, tannins, and curcumins can inhibit such type of ailments by the inhibition of pro-inflammatory enzymes such as cyclooxygenase (COX) and lipoxygenases (LOX) in the inflammatory cascades or their free radical scavenging activities [31,32]. Flavonoids are polyphenol group compounds that inhibit prostaglandins synthesis [33]. Medicinal plants may, 
therefore, be potential sources of COX-2/LOX inhibitors that may have fewer side effects than NSAIDs [34].

The purpose of the study is to evalute the antioxidative and anti-inflammatory activities of MP. This review is to provide information for further research on antioxidative and anti-inflammatory profiles of MP. This study may also give advantage to discover the new drug shortly.

\section{Methodology}

\subsection{Search Strategy}

The study was conducted to search the relevant studies on the antioxidant and anti-inflammatory properties of M. pumilum. The three online databases such as Scopus, EBSCOhost and Ovid Medline were retrieved to identify the studies. The articles included were published between 1946 and November 2017. The following two sets of keywords, (1) Kacip Fatimah OR Labisia pumila* OR Marantodes pumilum* OR Ardisia pumila* AND (2) *inflammat* OR *oxida* were used as the search strategy. Furthermore, the references to all retrieved articles were reviewed for relevant citations.

\subsection{Selection Criteria}

Only the original articles published in English language were included in this review. Articles on antioxidant and/ or anti-inflammatory activities of $M$. pumilum were also included. Review articles, books, book chapters, news, conference proceedings, editorial letters, or case studies were excluded from this study.

\subsection{Articles Screening}

Articles screening process was in three steps. Firstly, articles published as a review, book, book chapter, editorial letter, conference proceeding, case study or any other supplement were sorted out based solely on the title. Secondly, articles without relevant with the antioxidant and antiinflammatory properties of $M$. pumilum were excluded by reading the abstracts. Finally, the remaining articles did not match all inclusion criteria were excluded by reading thoroughly. After final screening, duplicate articles among the databases were removed. Then, articles were assessed for eligibility by checking all inclusion criteria and selected for final qualitative synthesis. This screening process has been done by two reviewers. Both reviewers were agreed that the included articles for the qualitative analysis in the review were fulfill the all inclusion criteria. Disagreements between the reviewers were resolved through a discussion. Data extraction was drawn in the data collection sheet for standardizing the data collection.

\subsection{Data Extraction Process}

The data was extracted based on characteristics of the studies including (1) study no (2) study design, (3) results, (4) outcomes and (5) ref. (Table 1). The data were also recorded based on phytochemistry of the studies such as (1) study no, (2) plant sources, (3) plant species, (4) plant parts, (5) type of extracts, (6) phytoconstituents, (7) ethnobotany and (8) ref. of each study (Table 2).

\section{Results}

\subsection{Search Results}

A total 512 potentially relevant articles was found by searching of three electronic databases. All articles were assessed independently by two reviewers for the screening process based on the inclusion and exclusion criteria. Seventy nine articles were related with reviews, books, book chapters, 
and conference papers. Another 406 articles did not measure parameters related to antioxidant and/ or anti-inflammatory activities of $M$. pumilum. So, total 485 articles were sorted out as primary screening. After the primary screening of abstracts, 27 articles remained. A total of 6 articles was removed due to duplicate between the databases. A total of 21 articles were selected for the final qualitative analysis. The remaining 21 articles fulfill all inclusion and exclusion criteria. Finally, these 21 articles were included in this review. A flowchart was drawn on the articles selection process is shown in Figure1, where including reasons for sorted out of articles.

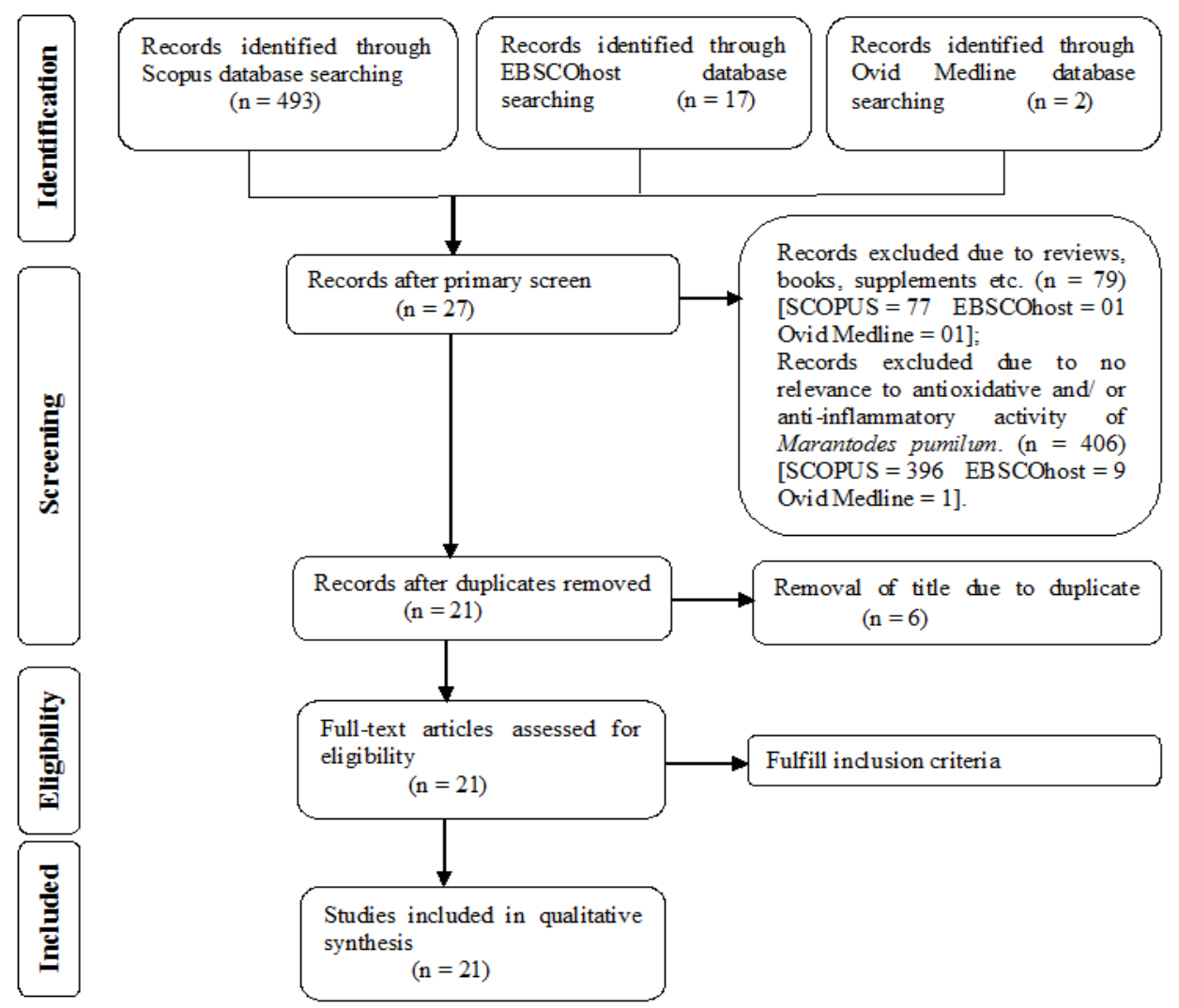

Figure 1. The Flowchart made according to PRISMA guideline shows the selection process of the articles in the review.

\subsection{Study Design Characteristics}

All studies were cheracterized in Table 1. All studies were published between the years 2009 to 2017 and consisted of twelve chemical assay studies, five animal studies, two in vitro cell culture study, one combined in vivo animal and chemical study and one combined chemical assay and in vitro cell culture study. Based on the types of activity, 16 studies focused on antioxidative activities, three studies focused on anti-inflammatory activities and two studies investigated both antioxidative and anti-inflammatory activities of M. pumilum. Animal studies used Sprague Dawley rats [35-37], Wistar rats [38-40] and ICR mice [36] as the experimental model. In the two in vitro cell culture studies were described in this review, where murine monocytic macrophage cell line RAW 264.7 was used in one study [41] and human peripheral blood mononuclear cells and plasma were used in another study [55]. Several chemical assays such as 1-diphenyl-2-picrylhydrazyl (DPPH) radical scavenging, ferric reducing antioxidant potential (FRAP), oxygen radical absorbance capacity (ORAC), oxygen $\left(\mathrm{O}_{2}\right)$ radical scavenging, hydrogen peroxide $\left(\mathrm{H}_{2} \mathrm{O}_{2}\right)$ radical scavenging, hydroxyl $(\mathrm{OH} \cdot)$ radical scavenging, $\beta$-carotene bleaching, nitric oxide (NO) radical scavenging and 2,2'-azino-bis(3-ethylbenzothiazoline6 -sulphonic acid) (ABTS) radical scavenging were used in the chemical studies [42-53]. Biochemical tests such as superoxide dismutase (SOD), glutathione peroxidise (GPx), and malondialdehyde (MDA) were also used to detect antioxidative activity [37-40]. Formalin-induced inflammation test, carrageenan-induced paw edema test and arachidonic acid-induced ear edema test were used to investigate anti-inflammatory activity in different studies [35,36]. Moreover, some inflammatory 
mediators and gene expressions including type-1 pro-collagen, tumor necrotic factor (TNF- $\alpha$ ), cyclooxygenase-2 (COX-2), matrix metalloproteinase-1 (MMP-1) and 9 (MMP-9) expression were analyzed to assess anti-inflammatory activities [54]. Most studies on antioxidative activity were carried out under different levels of environmental conditions such as different light source, $\mathrm{CO}_{2}$ concentration, organic and inorganic fertilizers [42-49].

Table 1. Characteristics of studies included in the review

\begin{tabular}{lllll}
\hline Study No & Study design & Results & Outcomes & Ref. \\
\hline 1 & nine weeks in vivo animal study & $\uparrow$ Significantly of SOD and GPx levels & MPva may & {$[37]$} \\
& $\begin{array}{l}\text { MPva extracts used. } \\
96 \text { female Sprague Dawley rats (aged } \\
3-5 \text { months and weight } 200-250 \mathrm{~g})\end{array}$ & $\begin{array}{l}\text { and } \downarrow \text { significantly MDA levels in treated } \\
\text { groups than control groups. } \\
\text { were randomly divided into six } \\
\text { groups. }\end{array}$ & & $\begin{array}{l}\text { via its anti- } \\
\text { oxidative } \\
\text { property. }\end{array}$ \\
& & &
\end{tabular}

Oxidative measurements include SOD, GPx and MDA levels of femora bone were assessed.

228 days in vivo animal study MPva extracts used. 54 male Wistar rats (weight 150 $200 \mathrm{~g}$ ) were randomly divided into nine groups.

Oxidative measurements include GPx, CAT and SOD levels in serum and myocardium homogenate were assessed.

28 days in vivo animal study

MPva extracts used.

54 male Wistar rats (weight 150 $200 \mathrm{~g}$ ) were randomly divided into nine groups.

Oxidative measurements include GSH, GR, and SOD levels in serum were assessed.

Eight weeks in vivo animal study MP extract used.

25 female Wistar rats (aged 3-4 months and body weight of 150-200g) were randomly divided into five groups. Oxidative measurements include MDA and SOD levels in serum were assessed.

Chemical assay study.

MPva and MPvp extracts used Antioxidative activity assay: DPPH free radical scavenging activity, FRAP, and $\beta$-Carotene bleaching assay Phytochemical content measurement: ascorbic acid, $\beta$-carotene, anthocyanin, TF, TP

Chemical assay study

MPva extracts used

Antioxidative activity assay: ORAC assay against $\mathrm{ROO}$ radical, $\mathrm{O}_{2}$ radical, $\mathrm{H}_{2} \mathrm{O}_{2}$ radical and $\mathrm{OH}$ radical Phytochemical content measurement: TP, TF, GSH, GSSG, and SC The experiment was done at different $\uparrow$ Significantly of GPx, CAT and SOD levels in treated groups than control groups.

$\uparrow$ Significantly of GSH, GR and SOD levels in treated groups than control groups.

\section{$\downarrow$ Significantly of MDA and $\uparrow$ significantly of SOD levels in treated groups than control groups.}

Found antioxidative activity in both MPva and MPvp extracts.

MPva contained higher antioxidative activities in all three methods applied including DPPH, FRAP, and $\beta$-carotene bleaching methods compared to MPvp.

Higher content of ascorbic acid, $\beta$ carotene, and anthocyanin in MPva compared to MPvp.

Higher content of total flavonoid in MPvp than MPva.

No significant difference of total phenolic content in between two extracts

Found antioxidative activity in both MPva.

$\uparrow$ Antioxidative activities of ROO, $\mathrm{O}_{2}$, $\mathrm{H}_{2} \mathrm{O}_{2}$, and $\mathrm{OH}$ of MPva at elevated $\mathrm{CO}_{2}$. Found phytochemical compounds like TP, TF, GSH, GSHH, and SC in MPva extract which might be enhanced antioxidative properties.
MPva may have cardioprotective effects due to its anti-oxidative property.

MPva may reduce the risk of dyslipidemia by modulating serum antioxidants.

\section{MP may}

normalize oxidative stress.

$$
\begin{aligned}
& \text { Antioxidative } \\
& \text { properties } \\
& \text { identified in both } \\
& \text { MP species. }
\end{aligned}
$$

MPva has antioxidative properties. 
levels of $\mathrm{CO}_{2}$.

$7 \quad$ Chemical assay study

MPva extracts used

Antioxidative activity assay: APX,

CAT, SOD and PAL activities

determined

Phytochemical content measurement:

TP, TF, AA and Protein content

The experiment was done under different potassium fertilization.

Chemical assay study

MPva extracts used

Antioxidative activity assay: DPPH

Radical Scavenging and PAL activities determined

Phytochemical content measurement:

TP, TF and AC content

The experiment was done at different

levels of irradiances.

Chemical assay study

MPva extracts used

Antioxidative activity assay: DPPH

Radical Scavenging and FRAP assay

Phytochemical content measurement:

TF, GSH, GSSG, AC and AA content

The experiment was done under

different nitrogen fertilization treatments.

Chemical assay study

MPva extracts used

Antioxidative activity assay: DPPH

Radical Scavenging and FRAP assay

Phytochemical content measurement:

TP, TF, TS, AA, SS, nitrate and GSH content

The experiment was done under

different treatments organic and

inorganic fertilizers.

Chemical assay study

MPva extracts used

Antioxidative activity assay: DPPH

Radical Scavenging and PAL activities determined

Phytochemical content measurement:

TP, TF, AC, AA, SS and MDA

content

The experiment was done at different levels of $\mathrm{CO}_{2}$ and light intensity.

Chemical assay study

Three extracts of MPva, MPvp, and

MPvl were used in the study.

Antioxidative activity assay: DPPH

Radical Scavenging, FRAP assay, and PAL activity measured.
The APX, CAT, SOD and PAL activities were found in MPva extract.

$\uparrow$ Significantly antioxidant enzymes activity including APX, CAT, SOD, and

PAL of MPva at elevated potassium

fertilization.

A TP, TF, AA, Protein and PAL content in the leaves of MPva followed by stems and roots and these secondary metabolites have a significant negative relationship with antioxidant enzymes activity under high potassium fertilization.

DPPH and PAL antioxidant activities were found in MPva

$\Delta$ Antioxidant activity in leaves of MPva followed by the stems and the roots in all levels of irradiances.

$\Delta$ Secondary metabolites like TP, TF and $\mathrm{AC}$ content in leaves followed by the stems and the roots of MPva.

PAL activity had significant positive relationships with secondary metabolites

A DPPH and FRAP antioxidant activities in the leaves followed by stems and roots of MPva in all nitrogen application treatments.

Antioxidant activities (DPPH and FRAP) have significant positive correlation and secondary metabolites (TF, GSH, GSSG, $\mathrm{AC}$, and $\mathrm{AA}$ ) suggesting that an increase in the antioxidative activities in MPva at low nitrogen fertilization could be induced to higher contents of these compounds.

$\Delta$ DPPH and FRAP antioxidant activities in the leaves followed by stems and roots of MPva under organic fertilization and $\boldsymbol{\nabla}$ inorganic fertilization. $\uparrow$ TP, TF, TS, AA, SS \& GSH content and $\downarrow$ nitrate content in MPva under organic fertilizers compared to the use of inorganic fertilizers.

DPPH and PAL activities were influenced by the interaction between elevated $\mathrm{CO}_{2}$ and irradiance levels

$\uparrow$ Antioxidant activities of DPPH and PAL in MPva with increasing $\mathrm{CO}_{2}$ and decreasing of irradiance.

$\uparrow \mathrm{TP}, \mathrm{TF}, \mathrm{AC}, \mathrm{AA} \& \mathrm{SS}$ content and $\downarrow$ MDA levels in MPva under high $\mathrm{CO}_{2}$ and low irradiance.

The production of secondary metabolites (TP, TF, AC, AA \& SS) displayed a significant positive relationship with enhanced the antioxidant activity (DPPH) of MPva.

$\uparrow$ Antioxidant activities of DPPH, FRAP, and PAL in all three varieties of LP with increasing $\mathrm{CO}_{2}$

$\Delta$ Phenolic compounds found in MPva followed by MPvp and MPvl and $\mathbf{\Delta}$ flavonoid compounds and PAL activity
Antioxidant

Antioxidant were found in MPva.

Antioxidative activity was found in MPva

MPva can be used

as a primary

antioxidant

Antioxidant activity was highest under organic fertilizer.

MPva had excellent free radical scavenging activity.

All three varieties of MP can be used as a primary antioxidant 
Phytochemical content measurement: $\mathrm{TP}$ and TF content

The experiment was done at different levels of $\mathrm{CO}_{2}$.

Chemical assay study

Extracts of three varieties MP including MPva, MPvp, and MPvl with three different parts including leaf, stem, and root were used in the study

Antioxidative activity assay: DPPH

Radical Scavenging and FRAP assay

Phytochemical content measurement:

Chemical assay study

Extracts of three varieties MP including MPva, MPvp, and MPvl with three different parts including leaf, stem, and root were used in the study.

Antioxidative activity assay: DPPH

Radical Scavenging and FRAP assay

Phytochemical content measurement: TP and TF content

The experiment was done under different levels of light intensity.

Chemical assay study

Extracts of three varieties MP including MPva, MPvp, and MPvl with three different parts including leaf, stem, and root were used in the study

Antioxidative activity assay: ABTS

Phytochemical content measurement: $\mathrm{TP}, \mathrm{TF}$, and TFA

The leaves and roots of the three the study

Anti-inflammatory activity assay:

Performed using NO production by macrophage RAW 264.7 cell lines induced by LPS/ IFN-g

In vivo animal study TP and TF content and NO scavenging assay found in MPvp followed by MPva and MPvl.

Gallic acid and quercetin were the most abundant phenolics and flavonoids respectively present in all the varieties. The production of secondary metabolites, PAL displayed a significant positive relationship with enhancing the antioxidant activity (DPPH \& FRAP) of LP under high $\mathrm{CO}_{2}$.

DPPH and FRAP antioxidative activities were found in different parts of all three varieties of LP

$\Delta$ Antioxidative activity of MPva contained than MPvp and MPvl.

$\Delta \mathrm{TP}$ and TF values in leaf compared to roots and stems.

$\Delta$ TF in MPvp than MPva and MPvl

$\Delta$ TP in MPva than MPvp and MPvl

DPPH and FRAP antioxidative activities were found in different parts of all three varieties of MP

$\uparrow$ Antioxidant activities of MP with increasing light intensity

$\Delta$ Antioxidative activity in leaf compared to roots and stems in all varieties of MP.

$\mathrm{TF}$ accumulation was highest in the leaves of MPvp and TP was highest in MPva under higher light intensity

The antioxidant activities of aqueous extracts obtained from MPva, MPvp, and $\mathrm{MPvl}$ in the reactions with ABTS radical and nitric oxide respectively. The obtained results revealed that the MPva contained higher antioxidative activities compared to MPvp and MPvl. TP and TF contents of leaves in all three varieties of LP were significantly different with each other. Fatty acids including palmitic, palmitoleic, linoleic, stearic, oleic, and $\alpha$ linolenic acid are the main components in three varieties of MP leaves.

DPPH, FRAP, and NO antioxidative activities were found in MP leaves extract.

$\uparrow$ Antioxidant activities of DPPH, FRAP and NO in LP leaves extract with increasing $\mathrm{CO}_{2}$.

$\uparrow$ significantly TP, TF, \& TFA content in MPva under high $\mathrm{CO}_{2}$ which are related to antioxidative effects and root extracts of all three varieties of MP including MPva, MPvp, and MPvl.

$\Delta$ Anti-inflammatory activity showed in root extracts compared to the leaf extracts.

$\downarrow$ Significantly formalin-induced paw licking time in $50 \mathrm{mg} / \mathrm{kg}$ extract treated $\downarrow$ Significantly NO production in the leaf

MP species have the potential to be a natural source of antioxidants

MP contained antioxidants

MP has antioxidants activities.

MP has antioxidants activities.

MP has anti-

MPvp leaf extract used in the study inflammatory activity.

MPvp could have 


\begin{abstract}
Anti-inflammatory activity assay:
Formalin-induced inflammation test and carrageenan-induced paw edema test. $60(30 \times 2)$ male Sprague-Dawley Rats (weight 120-290g) were taken and divided equally into two different five groups for formalin-induced inflammation test and carrageenaninduced paw edema test respectively.
\end{abstract}

In vivo animal and chemical assay study

Leave extract of MP (DELP) used in the study

Anti-inflammatory activities test: Arachidonic acid-induced ear edema was assessed by using mice model ( 20 ICR mice, 30-40g weight) to determined inhibitory activity and 35 male Sprague Dawley rats (6-8 month of age, weighing $150-200 \mathrm{~g}$ ) were divided equally into seven groups for mast cell stabilization test.

Antioxidative activities assay: DPPH radical scavenging, $\mathrm{O}_{2}$ radical scavenging, NO scavenging assay and TP content determined.

Chemical assay and in vitro cell culture study

MP extract used in the study Antioxidative activities assay: DPPH radical scavenging assessed Anti-inflammatory activities assay: Cell culture assessed Type-1 procollagen, TNF- $\alpha$, COX-2, MMP-1, MMP-9 expression.

In vitro cell culture study

The leaves and roots of the three species of MP extracts were used in the study

Anti-inflammatory activity assay:

Cytokine (IL-1 $\alpha$, IL-1 $\beta$, IL-6, IL-8, and TNF- $\alpha$ ) by using ELISA kits and prostaglandin $\mathrm{E}_{2}\left(\mathrm{PGE}_{2}\right)$ assay by using radioimmunoassay. group than other treated and control groups.

All treatments were able to suppress the edema formation induced by carrageenan as compared with the control.

$50 \mathrm{mg} / \mathrm{kg}$ of MP extract was found to be the best treatment. This treatment could reduce inflammation with highest inhibition of $64.59 \%$ followed by 25 $\mathrm{mg} / \mathrm{kg}$ with $56.99 \%$ and $10 \mathrm{mg} / \mathrm{kg}$ with $5.55 \%$.

DELP was able to prevent arachidonic acid-induced ear edema in the mice.

DELP was able to stabilize the mast cells and $\downarrow$ degranulated mast cells in the experimental rats.

$\mathrm{DPPH}, \mathrm{O}_{2}$ and $\mathrm{NO}$ radicals scavenging antioxidative activities were found in DELP.

Phenolic compounds were also found as gallic acid in DELP

DPPH radical scavenging antioxidative activities found in MP extract and $\boldsymbol{\Delta}$ than ascorbic acid

$\uparrow$ of TNF- $\alpha$ secretion, COX- 2 expression, MMP-1 and MMP-9 expression by inducing UVB (Ultraviolet B) irradiation and $\downarrow$ of TNF- $\alpha$ secretion, COX-2 expression, MMP-1 and MMP-9 expression by treating of MP extract. Restored of collagen and fibroblast synthesis by treating MP extract.

Maximum inhibition of IL- $1 \alpha$, IL- $1 \beta$, IL6 , IL-8, and TNF- $\alpha$ release by treating MPvl roots extract than other groups. Maximum inhibition of $\mathrm{PGE}_{2}$ release by treating MPvp roots extract compared to other groups. inflammatory activity

DELP may enhance antiinflammatory and antioxidant activity.

MP may have antioxidant activity and antiinflammatory effects.

MPvp and MPvl are potential for anti-inflammatory agents.
[36] 
39, 42-47,51]. Some studies have been conducted all of these three species of M. pumilum [41,48-50, $52,55]$. There were only two studies on the other M. pumilum species, one on M. pumilum var. pumila [35] and the other study using both M. pumilum var. pumila and var. alata [53]. Three studies did not mention the M. pumilum species used [36,40,54].

Table 2. Phytochemistry and ethnobotany of MP among the studies included in the review

\begin{tabular}{|c|c|c|c|c|c|c|c|}
\hline $\begin{array}{l}\text { Study } \\
\text { No. }\end{array}$ & $\begin{array}{l}\text { Plant } \\
\text { Sources }\end{array}$ & $\begin{array}{l}\text { Plant } \\
\text { Species }\end{array}$ & $\begin{array}{l}\text { Plant } \\
\text { parts }\end{array}$ & $\begin{array}{l}\text { Type of } \\
\text { extracts }\end{array}$ & Phytoconstituents & Ethnobotany & Ref. \\
\hline 1 & $\begin{array}{l}\text { Delima Jelita } \\
\text { Herbs, } \\
\text { Kedah, } \\
\text { Malaysia }\end{array}$ & MPva & $\begin{array}{l}\text { Whole } \\
\text { plant }\end{array}$ & Aqueous & - & Antioxidative & {$[37]$} \\
\hline 2 & $\begin{array}{l}\text { Hill tracks, } \\
\text { Perak, } \\
\text { Malaysia }\end{array}$ & MPva & $\begin{array}{l}\text { Whole } \\
\text { plant }\end{array}$ & $\begin{array}{l}\text { Aqueous, } \\
80 \% \text { ethanol }\end{array}$ & $\begin{array}{l}\text { Flavonoids (rutin \& myricetin), } \\
\text { phenolic (gallic acid), 5-( } Z \text { - } \\
\text { nonadec-14-enyl)resorcinol and } \\
\text { demethylbelamcandaquinone B }\end{array}$ & Antioxidative & [38] \\
\hline 3 & $\begin{array}{l}\text { Hill tracks, } \\
\text { Perak, } \\
\text { Malaysia }\end{array}$ & MPva & $\begin{array}{l}\text { Whole } \\
\text { plant }\end{array}$ & $\begin{array}{l}\text { Aqueous, } \\
80 \% \text { ethanol }\end{array}$ & $\begin{array}{l}\text { Flavonoids (rutin \& myricetin), } \\
\text { phenolic (gallic acid), 5-( } Z \text { - } \\
\text { nonadec-14-enyl)resorcinol and } \\
\text { demethylbelamcandaquinone B }\end{array}$ & Antioxidative & [39] \\
\hline 4 & - & MP & & Ethanol & - & Antioxidative & [40] \\
\hline 5 & - & $\begin{array}{l}\text { MPva } \\
\text { and } \\
\text { MPvp }\end{array}$ & Leaf & $\begin{array}{l}\text { Aqueous, } \\
80 \% \\
\text { Methanol }\end{array}$ & $\begin{array}{l}\text { Flavonoids (kaempferol), phenolic } \\
\text { compounds (gallic acid), } \\
\text { anthocyanin (petunidin), ascorbic } \\
\text { acid, } \beta \text {-carotene }\end{array}$ & Antioxidative & {$[53]$} \\
\hline 6 & $\begin{array}{l}\text { Glasshouse } \\
\text { complex of } \\
\text { University } \\
\text { Putra } \\
\text { Malaysia }\end{array}$ & MPva & $\begin{array}{l}\text { Leaf, } \\
\text { Stem } \\
\text { and } \\
\text { Root }\end{array}$ & $\begin{array}{l}\text { Methanol, } \\
80 \% \text { ethanol }\end{array}$ & $\begin{array}{l}\text { Flavonoids (rutin), phenolic (gallic } \\
\text { acid) and Glutathione }\end{array}$ & Antioxidative & [42] \\
\hline 7 & $\begin{array}{l}\text { Glasshouse } \\
\text { complex of } \\
\text { University } \\
\text { Putra } \\
\text { Malaysia }\end{array}$ & MPva & $\begin{array}{l}\text { Leaf, } \\
\text { Stem } \\
\text { and } \\
\text { Root }\end{array}$ & $\begin{array}{l}\text { Methanol, } \\
80 \% \text { ethanol }\end{array}$ & $\begin{array}{l}\text { Flavonoids (rutin), phenolic } \\
\text { compounds (gallic acid), ascorbic } \\
\text { acid, soluble sugar, Starch, non- } \\
\text { structural carbohydrate }\end{array}$ & Antioxidative & [43] \\
\hline 8 & $\begin{array}{l}\text { Glasshouse } \\
\text { complex of } \\
\text { University } \\
\text { Putra } \\
\text { Malaysia }\end{array}$ & MPva & $\begin{array}{l}\text { Leaf, } \\
\text { Stem } \\
\text { and } \\
\text { Root }\end{array}$ & $\begin{array}{l}\text { Methanol, } \\
80 \% \text { ethanol }\end{array}$ & $\begin{array}{l}\text { Flavonoids (quercetin), phenolic } \\
\text { compounds (gallic acid), } \\
\text { anthocyanin }\end{array}$ & Antioxidative & [44] \\
\hline 9 & $\begin{array}{l}\text { Glasshouse } \\
\text { complex of } \\
\text { University } \\
\text { Putra } \\
\text { Malaysia }\end{array}$ & MPva & $\begin{array}{l}\text { Leaf, } \\
\text { Stem } \\
\text { and } \\
\text { Root }\end{array}$ & $\begin{array}{l}\text { Methanol, } \\
80 \% \text { ethanol }\end{array}$ & $\begin{array}{l}\text { Flavonoids (quercetin), } \\
\text { anthocyanin, ascorbic acid, } \\
\text { glutathione }\end{array}$ & Antioxidative & [47] \\
\hline 10 & $\begin{array}{l}\text { Glasshouse } \\
\text { complex of } \\
\text { University } \\
\text { Putra } \\
\text { Malaysia }\end{array}$ & MPva & $\begin{array}{l}\text { Leaf, } \\
\text { Stem } \\
\text { and } \\
\text { Root }\end{array}$ & $\begin{array}{l}\text { Methanol, } \\
80 \% \text { ethanol }\end{array}$ & $\begin{array}{l}\text { Flavonoids (rutin), phenolics (gallic } \\
\text { acid), saponins (diosgenin), ascorbic } \\
\text { acid, soluble sugar (sucrose), } \\
\text { nitrate, glutathione }\end{array}$ & Antioxidative & [45] \\
\hline 11 & $\begin{array}{l}\text { Glasshouse } \\
\text { complex of } \\
\text { University } \\
\text { Putra } \\
\text { Malaysia }\end{array}$ & MPva & $\begin{array}{l}\text { Leaf, } \\
\text { Stem } \\
\text { and } \\
\text { Root }\end{array}$ & $\begin{array}{l}\text { Methanol, } \\
80 \% \text { ethanol }\end{array}$ & $\begin{array}{l}\text { Flavonoids (rutin), phenolics (gallic } \\
\text { acid), anthocyanin (petunidin), } \\
\text { ascorbic acid, soluble sugar } \\
\text { (sucrose), malondialdehyde }\end{array}$ & Antioxidative & [46] \\
\hline 12 & $\begin{array}{l}\text { Glasshouse } \\
\text { complex of } \\
\text { University } \\
\text { Putra } \\
\text { Malaysia }\end{array}$ & $\begin{array}{l}\text { MPva, } \\
\text { MPvp, } \\
\text { and } \\
\text { MPvl }\end{array}$ & Leaf & Methanol & $\begin{array}{l}\text { Flavonoids (kaempferol, quercetin, } \\
\text { myricetin, rutin \& naringenin) and } \\
\text { phenolics (gallic acid, pyrogallol \& } \\
\text { caffeic acid) }\end{array}$ & Antioxidative & {$[48]$} \\
\hline 13 & Kota Tinggi, & MPva, & Leaf, & Methanol & Flavonoids (rutin) and phenolics & Antioxidative & [50] \\
\hline
\end{tabular}




\begin{tabular}{|c|c|c|c|c|c|c|c|}
\hline & $\begin{array}{l}\text { Johor; Hulu } \\
\text { Langat, } \\
\text { Selangor; } \\
\text { and Sungkai, } \\
\text { Perak. }\end{array}$ & $\begin{array}{l}\text { MPvp, } \\
\text { and } \\
\text { MPvl }\end{array}$ & $\begin{array}{l}\text { Stem } \\
\text { and } \\
\text { Root }\end{array}$ & & (gallic acid) & & \\
\hline 14 & $\begin{array}{l}\text { Glasshouse } \\
\text { complex of } \\
\text { University } \\
\text { Putra } \\
\text { Malaysia }\end{array}$ & $\begin{array}{l}\text { MPva, } \\
\text { MPvp, } \\
\text { and } \\
\text { MPvl }\end{array}$ & $\begin{array}{l}\text { Leaf, } \\
\text { Stem } \\
\text { and } \\
\text { Root }\end{array}$ & Methanol & $\begin{array}{l}\text { Flavonoids (kaempferol, myricetin, } \\
\text { naringin, quercetin \& rutin) and } \\
\text { phenolics (gallic acid, pyrogallol \& } \\
\text { caffeic acid) }\end{array}$ & Antioxidative & [49] \\
\hline 15 & $\begin{array}{l}\text { Kota Tinggi, } \\
\text { Johor; Hulu } \\
\text { Langat, } \\
\text { Selangor; } \\
\text { and Sungkai, } \\
\text { Perak. }\end{array}$ & $\begin{array}{l}\text { MPva, } \\
\text { MPvp, } \\
\text { and } \\
\text { MPvl }\end{array}$ & Leaf & $\begin{array}{l}\text { Microwave } \\
\text { aqueous }\end{array}$ & $\begin{array}{l}\text { Flavonoids (rutin), phenolics (gallic } \\
\text { acid) and fatty acids (palmitic acid, } \\
\text { palmitoleic acid, stearic acid, } \\
\text { vaccenic acid, linoleic acid } \& \alpha \text { - } \\
\text { linolenic acid) }\end{array}$ & Antioxidative & [52] \\
\hline 16 & - & MPva & Leaf & $\begin{array}{l}\text { Aqueous, } \\
80 \% \\
\text { Methanol }\end{array}$ & $\begin{array}{l}\text { Flavonoids (rutin, myricetin, } \\
\text { quercetin, naringin, epicatechin, } \\
\text { catechin \& daidzein), phenolics } \\
\text { (gallic acid \& pyrogallol), saponin } \\
\text { (diosgenin) and fatty acids (palmitic } \\
\text { acid, palmitoleic acid, stearic acid, } \\
\text { vaccenic acid, linoleic acid } \& \alpha \text { - } \\
\text { linolenic acid) }\end{array}$ & Antioxidative & [51] \\
\hline 17 & $\begin{array}{l}\text { Kota Tinggi, } \\
\text { Johor; Hulu } \\
\text { Langat, } \\
\text { Selangor; } \\
\text { and Sungkai, } \\
\text { Perak. }\end{array}$ & $\begin{array}{l}\text { MPva, } \\
\text { MPvp, } \\
\text { and } \\
\text { MPvl }\end{array}$ & $\begin{array}{l}\text { Leaf } \\
\text { and } \\
\text { root }\end{array}$ & $\begin{array}{l}\text { Microwave } \\
\text { aqueous }\end{array}$ & - & $\begin{array}{l}\text { Anti- } \\
\text { inflammatory }\end{array}$ & [41] \\
\hline 18 & $\begin{array}{l}\text { Universiti } \\
\text { Putra } \\
\text { Malaysia }\end{array}$ & MPvp & Leaf & Aqueous & - & $\begin{array}{l}\text { Anti- } \\
\text { inflammatory }\end{array}$ & [35] \\
\hline 19 & $\begin{array}{l}\text { Universiti } \\
\text { Putra } \\
\text { Malaysia }\end{array}$ & MP & Leaf & $\begin{array}{l}\text { Dichloro- } \\
\text { methane }\end{array}$ & Phenolics (gallic acid) & $\begin{array}{l}\text { Antioxidative \& } \\
\text { Anti- } \\
\text { inflammatory }\end{array}$ & [36] \\
\hline 20 & - & MP & $\begin{array}{l}\text { Whole } \\
\text { plant }\end{array}$ & Aqueous & - & $\begin{array}{l}\text { Antioxidative \& } \\
\text { Anti- } \\
\text { inflammatory }\end{array}$ & [54] \\
\hline 21 & $\begin{array}{l}\text { Hutan } \\
\text { Gunung } \\
\text { Bujang } \\
\text { Melaka, } \\
\text { Kampar, } \\
\text { Perak, } \\
\text { Malaysia. }\end{array}$ & $\begin{array}{l}\text { MPva, } \\
\text { MPvp, } \\
\text { and } \\
\text { MPvl }\end{array}$ & $\begin{array}{l}\text { Leaf } \\
\text { and } \\
\text { root }\end{array}$ & $\begin{array}{l}\text { Dichloro- } \\
\text { methane, } \\
\text { Methanol, } \\
\text { aqueous }\end{array}$ & Quercetin and apigenin & $\begin{array}{l}\text { Anti- } \\
\text { inflammatory }\end{array}$ & [55] \\
\hline
\end{tabular}

The type of $M$. pumilum extracts used in the studies varies from each other. Readily dried powdered of $M$. pumilum has been used for the extraction in most of studies. Methanol and ethanol were used as a medium for extraction process in six studies [42-47]. Methanol and aqueous solutions were used individually for extraction in three [48-50] and five [35,37,41,52,54] of the studies, respectively. In the four studies, two of them were extracted by aqueous and ethanol process $[38,39]$ and another two were by aqueous and methanol process [51,53]. Each of two studies was used two different solvents including dichloromethane extract [36] and ethanol [40]. Only one study has been extracted in three different medium such as dichloromethane, methanol and aqueous [55]. In most studies [42-47,49,50], extracts from all parts of M. pumilum (leaf, stem, and root) were used. In two studies [41,55], two types of extract (leaf and root) have been used. In six studies [35,36,48,51-53], leaf extracts were used, and in the other four studies [37-39,54], whole plant extract was used. In most of the studies, plants were collected from Universiti Putra Malaysia, Serdang, while others were 
collected from Selangor; Perak and Johor. Phytoconstituents were identified in sixteen of the studies [36,38,39,42-53,55] which include flavonoids, phenolic compounds, saponins, fatty acids, ascorbic acids, anthocyanin, glutathione, nitrate, and sugars. Examples of flavonoids identified in all three varieties of M. pumilum were kaempferol, myricetin, naringin, quercetin, and rutinare. Examples of phenolic compounds identified were gallic acid, pyrogallol, caffeic acid, demethylbelamcandaquinone $\mathrm{B}$ and 5-(Z-nonadec-14-enyl) resorcinol. Examples of fatty acids identified were linoleic acid, $\alpha$ linolenic acid, vaccenic acid, stearic acid, palmitic acid, and palmitoleic acid.

\subsection{Antioxidant and Anti-inflammatory Properties of M. pumilum}

In total twenty one studies, sixteen studies have shown antioxidative effects of M. pumilum which included four animal study and twelve chemical assays studies. Three studies have exhibited anti-inflammatory effects of $M$. pumilum, including one animal study and two in vitro cell culture study. The other two studies, an animal study and a combined cell culture and assay study, have shown both antioxidative and anti-inflammatory effects (Table 1). All types of studies (in vivo animal study, in vitro cell culture study and/or assay study) have demonstrated positive effects of M. pumilum extracts (parts or whole plant) on oxidation and inflammation conditions.

\section{Discussion}

\subsection{Antioxidative Activities of M. pumilum}

Nineteen studies observed the positive antioxidative activity of $M$. pumilum, including four animal study and fifteen chemical assay studies. In the animal studies, oxidative measurements were analyzed by various biochemical test including SOD, GPx, CAT, GSH, GR and MDA levels in rat model supplemented with $M$. pumilum extract [37-40]. One of chemical assay study by Ibrahim and Jaafar (2012a) also analyzed antioxidant enzymatic activities like APX, CAT and SOD levels. In these studies, the SOD, GPx, CAT, GSH, GR and APX levels exhibited a positive response to M. pumilum supplementation [44]. In the Effendy and Shuid (2014) study, SOD and GPx levels were significantly higher in M. pumilum treated groups than control groups [37]. In contrast, a significant change of MDA level in the treated groups at week 6 and 9. MDA in treated groups was significantly lower level compared to ovariectomized control group in the treatment period of week 6 and 9. Thus, M. pumilum supplementations may potential to reduce oxidative stress due to its antioxidant properties and subsequently prevent the bone loss. Similar trends have been shown in the other animal studies in case of antioxidant activity [38-40]. Antioxidant enzymes have played an important role by suppressing free radicals release and preventing the oxidation degredation of lipids [56]. Due to anti-oxidative activities, the anti-oxidative enzyme levels would be reduced as demonstrated by the low of antioxidant enzymes like SOD and GPx levels of ovariectomized rat model [57]. In the fifteen chemical assay studies, many chemical assays were conducted to assess antioxidative activities particularly DPPH, NO, ABTS radical scavenging, FRAP, ORAC, PAL and $\beta$-carotene bleaching. In most of the studies [36, 44-51, 53, 54], DPPH radical scavenging assay was conducted to determine antioxidant activity. In this method, an antioxidant can donate hydrogen atom and quench into the stable free radical. In all of the studies, DPPH radical scavenging of M. pumilum species was higher in leaves extract, followed by other two extracts, stems and roots extracts in different environmental conditions.

When the M. pumilum varieties were compared by DPPH radical scavenging assay, var. alata has more antioxidative properties followed by var pumila and var. lanceolata. The study indicated that DPPH scavenging of var. alata extracts may have high contents ofphenolic compounds, flavonoids and anthocyanins [58]. Besides, total antioxidant activity can also measure by FRAP assay. This method is very fast and accurate [59]. This assay measures the total antioxidant activity by the calculation of reducing power of ferric $\left(\mathrm{Fe}^{3+}\right)$ to ferrous $\left(\mathrm{Fe}^{2+}\right)$ [60]. In some studies [45,47-51,53], similar expressions in FRAP assay were shown as that in DPPH antioxidant activity. The FRAP activity in leaves extract was also higher compared to the stems, and roots extracts of M. pumilum. The antioxidant activity of dietary polyphenols can also measure by FRAP assay [61]. The antioxidant activity and the phytochemicals like total phenolics and flavonoids contents have a strong relationship 
[2,63]. Current study has shown that FRAP activity is directly proportionated with total flavonoids and total phenolics. Moreover, PAL activity was measured to assess antioxidant activity in four of the studies $[43,44,46,48]$. This activity was influenced by environmental conditions and secondary plant metabolites because PAL is a precursor to total phenolics and flavonoids biosynthesis [64]. Other antioxidative assays used which include ORAC [42], $\beta$-carotene [53], ABTS [52] and NO radical scavenging $[36,51,52]$ followed a similar trend of earlier activities.

Also, many secondary metabolites have been identified from $M$. pumilum including ascorbic acid, $\beta$-carotene, anthocyanin, flavonoid, phenolic, saponin, fatty acids and glutathione [36,42-53]. A previous study demonstrated that antioxidative effects has strong relationship with the contents of vitamins $\mathrm{C}$ and $\mathrm{E}$, total carotenes, total xanthophylls, tannins and total phenolic compaounds[65]. Correlation analyses revealed significant positive coefficients of antioxidant activities with secondary metabolites [24]. Some secondary metabolites such as saponin, phenolic, ascorbic acid, $\beta$-carotene, and anthocyanin were found to be higher in var. alata compared to var. pumila and var. lanceolata. However, var. pumila had higher total flavonoid content than var. alata and var. lanceolata [53]. In most of the studies [42-47, 49, 50], bioactive compounds (total phenolics and flavonoid) of $M$. pumilum were highly accumulated in the leaf than other plant parts. The similar trend of antioxidant effects could also be found in secondary metabolites of all the studies.

\subsection{Anti-inflammatory Activities of M. pumilum}

Four studies, which consisted of two animal studies and two in vitro cell culture studies, had measured anti-inflammatory activities. In the animal studies [35,36], the anti-inflammatory activity was determined by formalin-induced inflammation, arachidonic acid-induced ear edema, carrageenaninduced paw edema, and mast cell stabilization test. In the in vitro cell culture studies $[41,54,55]$, the anti-inflammatory activity was analyzed by determination of NO production, Type- 1 pro-collagen levels, TNF- $\alpha$, COX-2, MMP-1, MMP-9, IL-1 $\alpha$, IL-1 $\beta$, IL-6, IL-8 and PGE 2 expression. Sanusi et al. (2013) evaluated the anti-inflammatory effects of three concentrations of M. pumilum var. lanceolata aqueous leaf extract in a rat model by using two inflammatory models like paw licking by formalin induction and paw edema test by carrageenan induction. Paw licking in M. pumilum var. lanceolata treated groups has reduced significantly than control groups. A similar trend was shown in carrageenan-induced edema test. The edema formation was better reduction in the treatment of $M$. pumilum var. lanceolata group compared to the control groups. The results suggested that M. pumilum extracts can efficiently reduce acute inflammation. The leaf extract has the highest level of antiinflammatory contents compared to extracts from other parts of M. pumilum plant [62]. Chemical constituents may have impact of anti-inflammatory activity. Moreover, several studies have also shown that flavonoids such as rutin, hesperidin and bioflavonoids could produce significant antiinflammatory activities [66,67]. Therefore, it is suggested that $M$. pumilum extract possesses a similar effect like Crocus sativus extract which contains a large amount of flavonoids which enhanced the anti-inflammatory effect. Besides, Ekeuku and Okechukwu (2013) investigated on the inhibition of arachidonic acid-induced ear edema by using $M$. pumilum extracts in mice model and determined its effect on mast cell stabilization using male rat model [36]. M. pumilum extract has potential against ear edema in mice and stabilize mast cells in experimental rats. Moreover, Karimi et al. (2013) demonstrated that the anti-inflammatory activity of leaves extract of three M. pumilum species was evaluated through in vitro cell culture [41]. This study demonstrated that NO release has significantly went down in all $M$. pumilum species. However, the activity of root extracts was better than the leaves extracts of all M. pumilum species. Kim et al. (2005) reported that iNOS has been extended levels in various types of cancer and chronic inflammatory diseases [68]. Thus, NO can induce inflammation and subsequently develop the cancer. Furthermore, Choi et al., (2010) analyzed TNF- $\alpha$, COX-2, collagen type-1, MMP-1 and MMP-9 expressions during inflammatory process induced by UV irradiation [54]. Treatment with M. pumilum extracts markedly inhibited TNF- $\alpha$ production, COX-2, and MMP-1 expressions and enhanced collagen production and MMP-9 expression. UVB irradiation can stimulate of skin cells to release of pro-inflammatory cytokines like TNF- $\alpha$, IL- $1 \alpha$, IL- 6 and inflammatory mediator like $\mathrm{PGE}_{2}$ in keratinocytes [69,70]. Thus, inflammation can prevent by controlling the pro-inflammatory mediators. Also, elevated expression of MMP-9 cause apoptosis, 
photoaging of skin epidermis [71]. The study results showed that $M$. pumilum extract has better effects against the photo aging in epidermis layer induced by UV compared to the ascorbic acid.

\section{Limitations and Recommendations}

This systematic review analyzed sixteen studies investigating the antioxidant and antiinflammatory activities of $M$. pumilum. Most of the studies were based on chemical assays. There was no human study carried out about these two activities of $M$. pumilum. All the studies on the antioxidative and anti-inflammatory activities of $M$. pumilum were carried out using chemical assays and highlighted phytochemical profiling in various environmental aspects except for five studies $[35,37,40,41,54]$. All the studies did confirm the antioxidative effects of $M$. pumilum except for three studies $[35,41,55]$.

Based on the potential shown by M. pumilum, it is recommended that further studies on the antioxidative and anti-inflammatory properties of $M$. pumilum extracts should be carried out in many more animal and human studies. Apart from this, studies are also needed to determine the phytochemical compounds responsible for these MP activities. These will support future studies on the specific active compounds of $M$. pumilum in the quest to discover new antioxidative and antiinflammatory agents.

\section{Conclusions}

The above literatures concluded that $M$. pumilum extracts have antioxidative and antiinflammatory activities. These activities are exhibited because of its phytoconstituents such as flavonoids, phenolics, ascorbic acid, beta-carotene, anthocyanin and fatty acids. MP has potential to be developed as alternative treatments for diseases related to oxidative and inflammatory conditions.

\section{Conflict of interest}

The authors confirm that this article content has no conflicts of interest.

\section{Acknowledgments}

Authors would like to thank the Faculty of Medicine Universiti Kebangsaan Malaysia for providing the resources for writing this systematic review and funding from NKEA Herbal Research Grant Scheme (NRGS) by the Ministry of Agriculture and Agro-based Industry, Malaysia.

\section{ORCID}

Shihab Uddin Ahmad :

Atiqa Azam : :0000-0002-3793-9025

Ahmad Nazrun Shuid : $0000-0003-3526-990 X$

Isa Naina Mohamed : 0000-0001-8891-2423

\section{References}

[1] S. Elliot and J. Brimacombe (1986). Pharmacy Needs Tropical Forests, Manuf. Chem. 57, 33- 34.

[2] The Plant List (2013). Version 1.1. Published on the Internet; http://www.theplantlist.org/ (accessed 1st July 2017).

[3] R.M. Ali and A.S. Zainon (2003). Database on ASEAN Herbal and Medicinal Plants. vol.1, ASEAN Publication.

[4] B. Sunarno (2005). Revision of the genus Labisia (Myrsinaceae), Blumea-Biodivers., Evol.Biogeograph. Plants 50, 579-597. 
[5] B.C. Stone (1989). New and Noteworthy Malesian Myrsinaceae, III. On the Genus Ardisia Sw. in Borneo, Proceed. Acad. Nat. Sci. Philadelphia 141, 263-306.

[6] B.C. Stone (1988). Notes on the genus labisia lindl.(Myrsinaceae), Malayan. Nat. J. 42, 43-51.

[7] M.H. Ibrahim, H.Z. Jaafar, A. Rahmat and Z.A. Rahman (2010). The relationship between phenolics and flavonoids production with total non structural carbohydrate and photosynthetic rate in Labisia pumila Benth. under high $\mathrm{CO}_{2}$ and nitrogen fertilization, $\quad$ Molecules 16, 162-174.

[8] Z. Muhamad and A.M. Mustafa (1994). Traditional Malay medicinal plants, Kuala Lumpur: Penerbit Fajar Bakti Sdn Bhd, 460-465.

[9] I. Burkill (1935). A Dictionary of the Economic Product of the Malay Peninsula, Vol 1 and 2. The Governments of the Straits Settlements and Federated Malay States, Kuala lumpur, Malaysia.

[10] U. Quattrocchi (2012). CRC world dictionary of medicinal and poisonous plants: common names, scientific names, eponyms, synonyms, and etymology (5 Volume Set). CRC Press, Boca Raton, Florida, United States.

[11] A.N. Shuid, L.L. Ping, N. Muhammad, N. Mohamed and I.N. Soelaiman (2011). The effects of Labisia pumila var. alata on bone markers and bone calcium in a rat model of post-menopausal osteoporosis, $J$. Ethnopharmacol. 133, 538-542.

[12] S.N. Fathilah, S. Abdullah, N. Mohamed and A.N. Shuid (2012). Labisia pumila prevents complications of osteoporosis byincreasing bone strength in a rat model of postmenopausal osteoporosis, Evid. Based Complement. Alternat. Med. $\mathbf{9 4 8 0 8 0 ,} 7$ pages.

[13] M. Fazliana, W.M. Wan Nazaimoon, H.F. Gu and C.G. Ostenson (2009). Labisia pumila extract regulates body weight and adipokines in ovariectomized rats, Maturitas 62, 91-97.

[14] A. Al-Wahaibi, W.W. Nazaimoon, W. Norsyam, H. Farihah and A. Azian (2008). Effect of water extract of Labisia pumila var Alata on aorta of ovariectomized Sprague Dawley rats, Pak. J. Nutr. 7, 208-213.

[15] J.A. Jamal, P. Houghton, S. Milligan and I. Jantan (2003). The oestrogenis and cytotoxiceffects of the extracts of Labisia pumila var. alata and Labisia pumila var. pumila in vitro, Sains Kesihatan. 1, 53-60.

[16] E. Karimi, H.Z. Jaafar and S. Ahmad (2011). Phytochemical analysis and antimicrobial activities of methanolic extracts of leaf, stem and root from different varieties of Labisa pumila Benth, Molecules 16, 4438-4450.

[17] A.H.L. Pihie, F. Othman and Z.A. Zakaria (2011). Anticarcinogenic activity of Labisia pumila against 7,12-dimethylbenz (a) anthracene (DMBA)/croton oil-induced mouse skin carcinogenesis, Afr. $J$. Pharm. Pharmacol. 5, 823-832.

[18] E. Karimi and H.Z. Jaafar (2011). HPLC and GC-MS determination of bioactive compounds in microwave obtained extracts of three varieties of Labisia pumila Benth, Molecules 16, 6791-6805.

[19] D.M.N. Hisham, J.M. Lip, J.M. Noh, A. Normah and M.N. Nabilah (2011). Identification and isolation of methyl gallate as a polar chemical marker for Labisia pumila Benth, J. Trop. Agric. and Fd. Sc. 39, 279-284.

[20] B. Avula, Y.H. Wang, Z. Ali, T.J. Smillie and I.A. Khan (2011). Quantitative determination of triperpene saponins and alkenated-phenolics from Labisia pumila using an LC-UV/ELSD method and confirmation by LC-ESI-TOF, Planta Med. 77, 1742-1748.

[21] N.A. Al-Mekhlafi, K. Shaari, F. Abas, R. Kneer, E.J. Jeyaraj, J. Stanslas, N. Yamamoto, T. Honda and N.H. Lajis (2012). Alkenylresorcinols and cytotoxic activity of the constituents isolated from Labisia pumila, Phytochemistry 80, 42-49.

[22] C. Proestos and M. Komaitis (2006). Ultrasonically assisted extraction of phenolic compounds from aromatic plants: comparison with conventional extraction technics, J. Food Qual. 29,567-582.

[23] R. Chaubal, V.H. Deshpande and N.R. Deshpande (2005). Methyl gallate, the medicinally important compound: A review, Electron. J. Environ. Agric. Food Chem. 4, 956-962.

[24] L.S. Chua, N.A. Latiff, S.Y. Lee, C.T. Lee, M.R. Sarmidi and R.A. Aziz (2011). Flavonoids and phenolic acids from Labisia pumila (Kacip Fatimah), Food Chem. 127, 1186-1192.

[25] W. Köpcke and J. Krutmann (2008). Protection from Sunburn with $\beta$-Carotene: A Meta-analysis, $J$. Photochem. Photobiol. 84, 284-288.

[26] M.D. Fotherby, J.C. Williams, L.A. Forster, P. Craner and G.A. Ferns (2000). Effect of vitamin C on ambulatory blood pressure and plasma lipids in older persons, J. Hypertens 18, 411-415.

[27] G. Polya (2003). Biochemical targets of plant bioactive compounds: A pharmacological reference guide to sites of action and biological effects. CRC press, Boca Raton, Florida, United States.

[28] E. Iwalewa, L. McGaw, V. Naidoo and J. Eloff (2007). Inflammation: The foundation of diseases and disorders. A review of phytomedicines of South African origin used to treat pain and inflammatory conditions, Afr. J. Biotechnol. 6, 2868-2885. 
[29] S. Fiorucci, R. Meli, M. Bucci and G. Cirino (2001). Dual inhibitors of cyclooxygenase and 5lipoxygenase. A new avenue in anti-inflammatory therapy?, Biochem. Pharmacol. 62, 1433-1438.

[30] H. P. Rang, J. M. Ritter, R. J. Flower and G. Henderson (1987). Rang \& Dale's Pharmacology, 8 ed. Harvard press, Churchill Livingstone, Edinburgh, UK.

[31] C.D. Sadik, H. Sies and T. Schewe (2003). Inhibition of 15-lipoxygenases by flavonoids: Structure-activity relations and mode of action, Biochem. Pharmacol. 65, 773-781.

[32] S.J. Lee, I.S. Lee and W. Mar (2003). Inhibition of inducible nitric oxide synthase and cyclooxygenase- 2 activity by $1,2,3,4,6$-penta-O-galloyl- $\beta$-D-glucose in murine macrophage cells,Arch. Pharm. Res. 26, 832-839.

[33] R.J. Nijveldt, E. Van Nood, D.E. Van Hoorn, P.G. Boelens, K. Van Norren and P.A. Van Leeuwen (2001). Flavonoids: A review of probable mechanisms of action and potential applications,Am. J. Clin. Nutr. 74, 418-425.

[34] I. Schneider and F. Bucar (2005). Lipoxygenase inhibitors from natural plant sources. Part 1: Medicinal plants with inhibitory activity on arachidonate 5-lipoxygenase and 5-lipoxygenase [sol] cyclooxygenase, Phytother. Res. 19, 81-102.

[35] R.A.M. Sanusi, N.A. Ab Shukor and M.R. Sulaiman (2013). Anti-inflammatory effects of Labisia pumila (Blume) F. Vill-Naves. aqueous extract, Sains Malaysiana. 42, 1511-1516.

[36] P.N. Okechukwu and S.O. Ekeuku (2013). Inhibition of arachidonic acid induced ear edema, mast cell stabilizing and free radical effect of dichloromethane crude extracts from the leaves of Labisia pumila, Asian J. Pharm. Clin. Res. 6, 93-95.

[37] N.M. Effendy and A.N. Shuid (2014). Time and dose-dependent effects of Labisia pumila on bone oxidative status of postmenopausal osteoporosis rat model, Nutrients 6, 3288-3302.

[38] R. Dianita, I. Jantan, A.Z. Amran and J. Jalil (2015). Protective effects of Labisia pumila var. alata on biochemical and histopathological alterations of cardiac muscle cells in isoproterenol-induced myocardial infarction rats, Molecules 20, 4746-4763.

[39] R. Dianita, I. Jantan, J. Jalil and A.Z. Amran (2016). Effects of Labisia pumila var alata extracts on the lipid profile, serum antioxidant status and abdominal aorta of high-cholesterol diet rats, Phytomedicine : Int. J. Phytother. phytopharmacol. 23, 810-817.

[40] N. Nurdiana, N. Mariati, N. Noorhamdani, B. Setiawan, N. Budhiparama and Z. Noor (2016). Effects of Labisia pumila on oxidative stress in rat model of post-menopausal osteoporosis, Asian Pac. J. Reprod. 5, 391-394.

[41] E. Karimi, H.Z. Jaafar and S. Ahmad (2013). Antifungal, anti-inflammatory and cytotoxicity activities of three varieties of Labisia pumila Benth: From microwave obtained extracts, BMC Complement. Altern. Med. 13, 20.

[42] M.H. Ibrahim and H.Z. Jaafar (2011). Increased carbon dioxide concentration improves the antioxidative properties of the Malaysian herb Kacip Fatimah (Labisia pumila Blume), Molecules 16, 6068-6081.

[43] M.H. Ibrahim and H.Z. Jaafar (2012). Reduced photoinhibition under low irradiance enhanced Kacip Fatimah (Labisia pumila Benth) secondary metabolites, phenyl alanine lyase and antioxidant activity, Int. J. Mol. Sci. 13, 5290-5306.

[44] M.H. Ibrahim, H.Z. Jaafar, E. Karimi and A. Ghasemzadeh (2012). Primary, secondary metabolites,photosynthetic capacity and antioxidant activity of the Malaysian Herb Kacip Fatimah (Labisia Pumila Benth) exposed to potassium fertilization under greenhouse conditions, Int. J. Mol. Sci. 13, 15321-15342.

[45] M.H. Ibrahim, H.Z. Jaafar, E. Karimi and A. Ghasemzadeh (2013).Impact of organic and inorganic fertilizers application on the phytochemical and antioxidant activity of Kacip Fatimah(Labisia pumila Benth), Molecules 18, 10973-10988.

[46] M.H. Ibrahim, H.Z. Jaafar, E. Karimi and A. Ghasemzadeh (2014). Allocation of secondary metabolites, photosynthetic capacity, and antioxidant activity of Kacip Fatimah (Labisia pumila Benth) in response to and light intensity, Sci. World J. 2014, 360290, 13 pages.

[47] M.H. Ibrahim, H.Z. Jaafar, A. Rahmat and Z.A. Rahman (2011). Involvement of nitrogen on flavonoids, glutathione, anthocyanin, ascorbic acid and antioxidant activities of Malaysian medicinal plant Labisia pumila Blume (Kacip Fatimah), Int. J. Mol. Sci. 13, 393-408.

[48] H.Z. Jaafar, M.H. Ibrahim and E. Karimi (2012). Phenolics and flavonoids compounds, phenylanine ammonia lyase and antioxidant activity responses to elevated $\mathrm{CO}_{2}$ in Labisia pumila (Myrisinaceae), Molecules 17, 6331-6347. 
[49] E. Karimi, H. Jaafar, A. Ghasemzadeh and M.H. Ibrahim (2013). Light intensity effects on production and antioxidant activity of flavonoids and phenolic compounds in leaves, stems and roots of three varieties of Labisia pumila Benth, Aust. J. Crop. Sci. 7, 1016-1023.

[50] E. Karimi, H.Z. Jaafar and S. Ahmad (2011). Phenolics and flavonoids profiling and antioxidant activity of three varieties of Malaysian indigenous medicinal herb Labisia pumila Benth, J. Med. Plants Res. 5, 1200-1206.

[51] E. Karimi, H.Z. Jaafar and A. Ghasemzadeh (2016). Chemical composition, antioxidant and anticancer potential of Labisia pumila variety alata under $\mathrm{CO}_{2}$ enrichment, NJAS-Wagen. J. Life Sci. 78, 85-91.

[52] E. Karimi, H.Z. Jaafar, A. Ghasemzadeh and M. Ebrahimi (2015). Fatty acid composition, antioxidant and antibacterial properties of the microwave aqueous extract of three varieties of Labisia pumila Benth, Biolog. Res. 48, 9.

[53] M. Norhaiza, M. Maziah and M. Hakiman (2009). Antioxidative properties of leaf extracts of a popular Malaysian herb, Labisia pumila, J. Med. Plants Res. 3, 217-223.

[54] H.K. Choi, D.H. Kim, J.W. Kim, S. Ngadiran, M.R. Sarmidi and C.S. Park (2010). Labisia pumila extract protects skin cells from photoaging caused by UVB irradiation, J. Biosci.Bioeng. 109, 291-296.

[55] E.P. Rahmi, J.A. Jamal, E. Kumolosasi, J. Jalil and N.A. Aladdin (2017). Marantodes pumilum (Blume) Kuntze inhibited secretion of lipopolysaccharide- and monosodium urate crystal-stimulated cytokines and plasma prostaglandin E2, Pharmacogn Mag. 13, 578-586.

[56] E. Niki, Y. Yoshida, Y. Saito and N. Noguchi (2005). Lipid peroxidation: mechanisms, inhibition, and biological effects, Biochem. Biophys. Res. Commun. 338, 668-676.

[57] S. Muthusami, I. Ramachandran, B. Muthusamy, G. Vasudevan, V. Prabhu, V. Subramaniam, A. Jagadeesa and S. Narasimhan (2005). Ovariectomy induces oxidative stress and impairs boneantioxidant system in adult rats, Clin. Chim. Acta. 360, 81-86.

[58] B.N. Tripathi, I. Bhatt and K.J. Dietz (2009). Peroxiredoxins: A less studied component of hydrogen peroxide detoxification in photosynthetic organisms, Protoplasma 235, 3.

[59] I.F. Benzie and J.J. Strain (1996). The ferric reducing ability of plasma (FRAP) as a measure of "antioxidant power": The FRAP assay, Anal. Biochem. 239, 70-76.

[60] G.-C. Yen and P.D. Duh (1994). Scavenging effect of methanolic extracts of peanut hulls on freeradical and active-oxygen species, J. Agric. Food Chem. 42, 629-632.

[61] A. Luximon-Ramma, T. Bahorun, M.A. Soobrattee and O.I. Aruoma (2002). Antioxidant activities of phenolic, proanthocyanidin, and flavonoid components in extracts of Cassia fistula, J. Agric. Food Chem. 50, 5042-5047.

[62] M.H. Ibrahim and H.Z. Jaafar (2011). The relationship of nitrogen and C/N ratio with secondary metabolites levels and antioxidant activities in three varieties of malaysian Kacip fatimah Labisia pumila Blume), Molecules 16, 5514-5526.

[63] M.I. Gil, F.A. Tomas-Barberan, B. Hess-Pierce and A.A. Kader (2002). Antioxidant capacities, phenolic compounds, carotenoids, and vitamin $\mathrm{C}$ contents of nectarine, peach, and plum cultivars from California, J. Agric. Food Chem. 50, 4976-4982.

[64] W. Li, P. He and J. Jin (2009). Potassium influenced phenylalanine ammonia-lyase, peroxidases and "polyphenol oxidases in Fusarium graminearum infected maize (Zea mays L.), in: The Proceedings of the International Plant Nutrition Colloquium XVI, eScholarship.org, The California Digital Library, University of California.

[65] A. Chanwitheesuk, A. Teerawutgulrag and N. Rakariyatham (2005). Screening of antioxidant activity and antioxidant compounds of some edible plants of Thailand, Food Chem. 92, 491-497.

[66] J.B. Calixto, A. Beirith, J. Ferreira, A.R. Santos, V.C. Filho and R.A. Yunes (2000). Naturally occurring antinociceptive substances from plants, Phytother. Res. 14, 401-418.

[67] M. Ramesh, Y.N. Rao, A.A. Rao, M. Prabhakar, C.S. Rao, N. Muralidhar and B.M. Reddy (1998). Antinociceptive and anti-inflammatory activity of a flavonoid isolated from Caralluma attenuata, J. Ethnopharmacol. 62, 63-66.

[68] Y.H. Kim, K.J. Woo, J.H. Lim, S. Kim, T.J. Lee, E.M. Jung, J.M. Lee, J.W. Park and T.K. Kwon (2005). 8-Hydroxyquinoline inhibits iNOS expression and nitric oxide production by down-regulating LPS-induced activity of NF- $\kappa \mathrm{B}$ and C/EBP $\beta$ in Raw 264.7 cells, Biochem Biophys. Res. Commun., 329, 591-597.

[69] S. Amano, Y. Ogura, N. Akutsu, Y. Matsunaga, K. Kadoya, E. Adachi and T. Nishiyama (2005). Protective effect of matrix metalloproteinase inhibitors against epidermal basement membrane damage: Skin equivalents partially mimic photoageing process, Br. J. Dermatol.153, 37-46.

[70] E. Jung, J. Lee, J. Baek, K. Jung, J. Lee, S. Huh, S. Kim, J. Koh and D. Park (2007). Effect of Camellia japonica oil on human type I procollagen production and skin barrier function, $J$. Ethnopharmacol. 112, 127-131. 
[71] S. Onoue, T. Kobayashi, Y. Takemoto, I. Sasaki and H. Shinkai (2003). Induction of matrix metalloproteinase-9 secretion from human keratinocytes in culture by ultraviolet B irradiation, J.Dermatol. Sci. 33, 105-111.

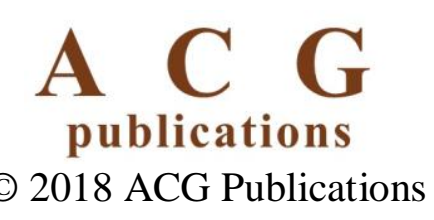

